\title{
Efektivitas functional communication training dalam meningkatkan perilaku meminta pada anak dengan autism spectrum disorder
}

\author{
Detricia Tedjawidjaja $^{1}$ dan Fenny Hartiani ${ }^{2}$
}

\begin{abstract}
The current study aims to examine the effectiveness of functional communication training to increase asking behavior by exchanging pictures for children with an autism spectrum disorder. The participant in this study is a 6-years old girl with a diagnosis of Autism Spectrum Disorder with Intellectual Impairment. This study uses a single-subject design consisting of A-B-A phases. Functional communication training is implemented using the most-to-least prompting technique which is divided into 8 sessions. The result depicts that an $84 \%$ of participants increase their ability to perform requesting behavior by exchanging pictures of the trials given. Furthermore, after the implementation of functional communication training, there is an increase in the frequency of requesting behavior by exchanging pictures at pasca-tes (average 74\%) and at follow-up (average $82 \%$ ). Implications of this study indicates the importance of considering the function of problem behavior in training the appropriate communicative responses for children with autism spectrum disorder.
\end{abstract}

\section{Keywords}

problem behavior, training, communicative response, experimental, children

\section{Pendahuluan}

Perkembangan bahasa sudah terjadi sejak seseorang berada pada masa bayi yang diawali dengan perilaku menangis dan berkembang menjadi perilaku berceloteh (Santrock, 2014). Perkembangan bahasa merupakan salah satu aspek perkembangan yang mendasar bagi individu untuk dapat berkomunikasi dengan orang lain. Dengan bahasa, seseorang dapat berbicara, mendengar, membaca, dan menulis. Bahasa membantu kita untuk dapat berbagi informasi, melakukan percakapan, hingga dapat membangun relasi sosial dengan orang lain (Mody \& Belliveau, 2012; Santrock, 2014). Namun, sayangnya, bahasa dan kemampuan komunikasi sosial tidak selalu berkembang secara normal pada setiap anak, salah satunya adalah pada anak dengan Autism Spectrum Disorder (ASD) (Mody \& Belliveau, 2012).

Gangguan pada perkembangan bahasa serta komunikasi sosial merupakan salah satu ciri khas yang muncul pada anak dengan ASD (Mody \& Belliveau, 2012; Williams \& Williams, 2011). Menurut DSM-5, ASD didefinisikan sebagai gangguan neurodevelopmental yang muncul pada masa perkembangan usia dini dan ditandai dengan dua karakteristik utama, yaitu defisit yang menetap dan signifikan pada interaksi dan komunikasi sosial dan adanya pola minat dan perilaku yang terbatas dan berulang (American Psychiatric Association, 2013). Pada saat anak tipikal sudah mampu menyebutkan kata pertama pada usia 12-18 bulan, sebagian besar anak dengan ASD menyebutkan kata pertama pada usia 38 bulan (Kim et al., 2014). Selain itu, pada usia 5 tahun, anak dengan ASD menunjukkan kemampuan bahasa ekspresif yang cenderung berbeda dan secara signifikan lebih lambat dibandingkan dengan anak tipikal (Kim et al., 2014; Mody \& Belliveau, 2012).

Salah satu perilaku verbal yang paling dasar dan penting dikuasai oleh seorang anak adalah mand yang mencakup perilaku meminta dan memberikan perintah (Williams \& Williams, 2011). Dengan menguasai perilaku verbal mand, setiap orang dapat memperoleh kebutuhan dan keinginannya (Williams \& Williams, 2011). Sayangnya, anak dengan ASD kesulitan mengekspresikan perasaan dan kebutuhannya (Konst et al., 2013). Mereka cenderung menunjukkan perilaku verbal mand yang primitif, seperti menggunakan bahasa tubuh untuk meminta sesuatu kepada orang lain (Mash \& Wolfe, 2016). Akibatnya, anak dengan ASD cenderung mudah merasa marah, frustrasi, cemas, dan depresi yang kemudian tampil dalam bentuk perilaku bermasalah, seperti tantrum (Konst et al., 2013). Selain itu,

\footnotetext{
${ }^{1}$ Fakultas Psikologi Universitas Katolik Widya Mandala Surabaya ${ }^{2}$ Fakultas Psikologi Universitas Indonesia

Korespondensi:

Tedjawidjaja, Fakultas Psikologi Universitas Indonesia

Email: detricia.tedjawidjaja@gmail.com
} 
orang tua dari anak dengan ASD rentan merasakan tekanan yang tinggi ketika anak mereka menunjukkan defisit dalam kemampuan interaksi dan komunikasi sosial yang parah (Rodriguez et al., 2019).

Salah satu intervensi yang terbukti secara empiris efektif menangani masalah anak dengan ASD adalah intervensi dengan pendekatan teori perilaku (Williams \& Williams, 2011). Pada tahun 1985, Carr dan Durrand mengembangkan Functional Communication Training (FCT), yaitu intervensi berbasis teori perilaku yang berfokus pada respon komunikatif yang mudah dikenali oleh orang lain (Carr \& Durand, 1985; Tiger et al., 2008). FCT menggunakan prosedur differential reinforcement yang mengajarkan suatu perilaku alternatif yang dapat menggantikan perilaku bermasalah yang sebelumnya ditampilkan (Martin \& Pear, 2015; Miltenberger, 2016; Carr \& Durand, 1985), FCT diterapkan kepada 4 anak dengan gangguan perkembangan yang menunjukkan perilaku bermasalah selama proses pembelajaran. Bagi anak yang perilaku bermasalahnya muncul karena ingin mendapatkan atensi guru, anak tersebut diajarkan respon komunikatif yang lebih baik untuk memperoleh atensi dari guru. Di sisi lain, bagi anak yang perilaku bermasalahnya muncul untuk menghindari tugas yang sulit, anak tersebut diajarkan respon komunikatif untuk memperoleh waktu istirahat. Dengan mengajarkan respon komunikatif yang baru, anak masih tetap mendapatkan yang ia inginkan tanpa perlu menggunakan perilaku bermasalah yang sebelumnya muncul (Carr \& Durand, 1985).

Dalam menerapkan FCT, terdapat tiga tahap yang perlu diperhatikan (Durand \& Moskowitz, 2015; Franzone, 2009; Tiger et al., 2008). Tahap pertama adalah Functional Behavioral Assessment (FBA), yaitu proses mengumpulkan informasi mengenai anteseden dan konsekuensi yang mengacu pada fungsi atau tujuan dari perilaku bermasalah muncul (Miltenberger, 2016). Selain itu, FBA juga dapat berfungsi untuk mengidentifikasi situasi yang menjadi reinforcer terhadap perilaku bermasalah dan kondisi-kondisi yang memicu munculnya perilaku bermasalah tersebut (Durand \& Moskowitz, 2015; Tiger et al., 2008).

Pada tahap 2, anak akan diajarkan respon komunikatif sebagai pengganti dari perilaku bermasalah (Franzone, 2009; Tiger et al., 2008). Seorang Pelaksana Intervensi (PI) perlu untuk memilih terlebih dahulu respon komunikatif apa yang ingin diajarkan antara lain meliputi respon vokal/lisan, penukaran gambar, bahasa isyarat, bahasa tubuh, atau aktivasi suara atau text output devices. Terdapat beberapa pertimbangan dalam menentukan respon komunikatif yang tepat, yaitu kemudahan respon komunikatif untuk dipelajari oleh anak dan dipahami oleh orang lain serta cepat tidaknya respon komunikatif untuk memperoleh reinforcer (Tiger et al., 2008). Setelah menentukan respon komunikatif, PI mulai menerapkan prosedur mostto-least prompting, yaitu prosedur membentuk suatu perilaku dengan menggunakan prompt dengan tingkat bantuan yang paling tinggi hingga prompt dengan tingkat bantuan yang paling rendah (Sarafino, 2012; Tiger et al., 2008). Prompt terbagi menjadi empat jenis, yaitu physical prompt, modelling prompt, gestural prompt, dan verbal prompt. Selain prompt, dibutuhkan adanya reinforcement untuk membentuk perilaku seseorang. Williams \& Williams (2011) menjelaskan bahwa perilaku verbal dapat terbentuk jika pembicara mendapatkan reinforcement melalui perilaku dari pendengar. Oleh karena itu, penting untuk mengidentifikasi benda-benda yang dapat menjadi reinforcement bagi anak sebelum prosedur most-to-least prompting diterapkan.

Setelah respon komunikatif sudah diajarkan kepada anak, tahap ketiga atau yang terakhir adalah menggeneralisasikan penerapan respon komunikatif (Tiger et al., 2008). Generalisasi dapat dilakukan dengan melibatkan beberapa orang dalam sesi pelatihan sehingga respon komunikatif muncul kepada berbagai pasangan komunikasi. Selain itu, teknik generalisasi lain yang dapat dilakukan adalah membuat agar setting pelatihan semirip mungkin dengan setting alami. Ada juga teknik generalisasi yang bisa dilakukan adalah mengajarkan respon komunikatif pada setting lain secara berkelanjutan (Tiger et al., 2008).

Hasil penelitian menunjukkan bahwa FCT telah berhasil meningkatkan fungsi komunikasi yang lebih mudah dipahami secara sosial pada anak dengan ASD, kerusakan otak, keterlambatan perkembangan, pervasive developmental disorder-not otherwise specified, dan disabilitas intelektual tingkat sedang (Anderson et al., 2016; Lambert et al., 2012; Rispoli et al., 2014; Wacker et al., 2017). Selain itu, hasil studi literatur dari 12 penelitian yang dilakukan oleh Andzik et al. (2016) menunjukkan bahwa FCT memberikan hasil yang positif terhadap partisipan, seperti penurunan dalam perilaku agresi, menyakiti diri sendiri, dan tantrum.

Sementara FCT sudah sering diterapkan di negara lain, di Indonesia sendiri, penelitian yang menguji efektivitas penerapan FCT masih sulit untuk ditemukan. Secara umum, penelitian di Indonesia telah membuktikan efektivitas prosedur differential reinforcement dalam menurunkan perilaku bermasalah dan meningkatkan perilaku yang diinginkan (Ardiwijaya \& Kuntoro, 2019; Stephanie \& Djuwita, 2019). Namun, prosedur differential reinforcement dalam penelitian tersebut berbeda dengan prosedur differential reinforcement dalam FCT karena bukan berfokus dalam meningkatkan respon komunikatif anak. Selanjutnya, intervensi lain yang seringkali diteliti di Indonesia untuk meningkatkan kemampuan komunikasi anak dengan ASD adalah Picture Exchange Communication System atau PECS (Heryati \& Ratnengsih, 2017; Jusoh \& Majid, 2017; Murwati, 2013; Putri et al., 2018; Vistasari \& Patria, 2019). Meskipun demikan, intervensi PECS tidak melibatkan proses identifikasi fungsi dari perilaku bermasalah yang ditunjukkan oleh anak dengan ASD.

Berdasarkan penelitan mengenai FCT yang minim di Indonesia, penelitian ini berusaha untuk menguji efektivitas FCT untuk meningkatkan respon komunikatif anak dengan ASD. Penelitian ini dilaksanakan dengan 
melibatkan satu orang partisipan anak berinisial $\mathrm{K}$, usia 6 tahun, yang mendapatkan diagnosis Autism Spectrum Disorder with accompanying Intellectual Impairment. Secara umum, perkembangan bahasa $\mathrm{K}$ jauh di bawah anak seusianya. Kemampuan bahasa ekspresif $\mathrm{K}$ terbatas sehingga ia menyampaikan hal yang ia inginkan dengan cara menggunakan bahasa tubuh, seperti dengan menarik tangan orang lain ke benda yang ia inginkan. Ketika orang lain tidak dapat memahami keinginan $\mathrm{K}$, ia akan merasa frustasi dan tampil dalam bentuk perilaku berteriak, menangis, hingga tantrum yang tidak terkontrol dalam durasi yang lama. Berdasarkan masalah yang dialami $\mathrm{K}$ tersebut, $\mathrm{K}$ menunjukkan adanya keterbatasan pada perilaku meminta dan membutuhkan suatu intervensi yang dapat membantu dirinya untuk menyampaikan permintaan yang lebih mudah dipahami oleh orang lain. Dengan demikian, penelitian ini ingin menguji efektivitas FCT dalam meningkatkan penguasaan dan frekuensi perilaku meminta pada anak dengan ASD.

\section{Metode}

Partisipan diperoleh di Klinik Terpadu Psikologi Universitas Indonesia dengan menggunakan teknik purposive sampling. Penelitian ini mencari partisipan dengan rentang usia sekitar 5-12 tahun, telah didiagnosis dengan ASD, dan menunjukkan defisit komunikasi dan interaksi sosial yang berada pada level 3 (requiring very substantial support). Dengan kriteria tersebut, diperoleh seorang anak perempuan berusia 6 tahun dengan inisial $\mathrm{K}$ untuk menjadi partisipan dalam penelitian ini. Hasil pemeriksaan menunjukkan bahwa K didiagnosis dengan Autism Spectrum Disorder with accompanying Intellectual Impairment. K sulit melakukan kontak mata, tidak menoleh saat dipanggil, dan cenderung berkomunikasi secara nonverbal dengan menarik tangan orang lain ke arah benda yang ia inginkan. Sementara itu, gejala pola perilaku atau minat yang terbatas atau berulang berada pada level 2 (requiring substantial support). K menunjukkan minat terbatas pada jenis puzzle dan makanan tertentu, rigid terhadap rutinitas sehari-hari, serta menunjukkan hypersensitivity terhadap rangsang suara dan hyposensitivity pada rangsang sentuhan. Hasil tes inteligensi menunjukkan bahwa taraf kecerdasan $\mathrm{K}$ berada pada ketidakmampuan intelektual taraf sedang dengan skor IQ = 37 menurut skala StanfordBinet. Usia mentalnya setara dengan anak usia 2 tahun 7 bulan. Seluruh aspek inteligensi K berada di bawah rata-rata anak seusianya. Salah satu aspek kecerdasan $\mathrm{K}$ yang paling rendah adalah perkembangan bahasanya yang berada di bawah usia 2 tahun. K sebenarnya dapat menunjuk benda yang disebutkan dengan tepat (Misalnya, dapat menunjuk gambar topi, pisau, kursi, ola, dan lain sebagainya). Namun, $\mathrm{K}$ tidak dapat menyebutkan nama bendanya. K cukup mampu memahami perintah sederhana (Misalnya, perintah mengambil, menunjuk, memberikan). Namun, pada pertanyaan sederhana, seperti pertanyaan mau/tidak mau, $\mathrm{K}$ hanya dapat menjawab dengan berteriak dan marah jika yang ia maksud adalah tidak mau. Selain itu, K juga masih belum dapat berbicara secara spontan. Jika K mengucapkan suatu kata atau suku kata, K masih membutuhkan bantuan berupa contoh dari orang lain terlebih dahulu, seperti diberikan prompt verbal.

Mempertimbangkan keterbatasan $\mathrm{K}$ dalam kemampuan bicara secara verbal, perilaku meminta yang akan diajarkan kepada $\mathrm{K}$ adalah perilaku meminta nonverbal yang menggunakan penukaran gambar. Penukaran gambar merupakan bentuk komunikasi nonverbal yang dianggap sederhana dan biasanya berhasil diterapkan bagi anak dengan ASD dibandingkan dengan mengajarkan lisan atau menggunakan bahasa isyarat (Williams \& Williams, 2011). Selain itu, Tiger et al. (2008) menjelaskan bahwa penukaran gambar mudah dipahami oleh orang lain di sekitar anak maupun orang yang baru dikenal mengenai apa yang diinginkan oleh anak. Selanjutnya, penggunaan gambar lebih mudah untuk memperoleh atensi dari orang lain dengan menyentuh orang tersebut dan kemudian menunjukkan gambar dari benda yang diinginkan sehingga anak dapat memperoleh yang ia inginkan dengan cepat (Tiger et al., 2008). Dengan mempertimbangkan keuntungan menggunakan penukaran gambar dan mengacu pada kemampuan $\mathrm{K}$ yang sudah dapat mendiskriminasi gambar, respon komunikatif yang dipilih dan akan diajarkan dalam intervensi ini adalah perilaku meminta dengan penukaran gambar.

Intervensi FCT yang diberikan akan berfokus untuk (1) meningkatkan kemampuan $\mathrm{K}$ dalam menampilkan perilaku meminta dengan menukarkan gambar secara mandiri dan (2) meningkatkan frekuensi perilaku meminta dengan menukarkan gambar. Pada tujuan pertama, dimensi perilaku yang ingin dicapai berupa kemampuan $\mathrm{K}$ dalam menukarkan gambar. Sementara itu, pada tujuan kedua, dimensi perilaku yang ingin dicapai adalah frekuensi $\mathrm{K}$ dalam menukarkan gambar. Perilaku meminta dengan menukarkan gambar didefinisikan sebagai rangkaian perilaku yang mencakup: (1) Menuju ke papan komunikasi yang berisi kartu-kartu bergambar; (2) Memilih gambar benda yang diinginkan; (3) Mengambil gambar tersebut; dan (4) Memberikan gambar pada pasangan komunikasi.

Penelitian ini menggunakan intervensi FCT untuk meningkatkan kemampuan sekaligus frekuensi perilaku meminta dengan penukaran gambar pada 1 orang partisipan. Oleh karena itu, desain penelitian yang digunakan adalah single subject design yang terdiri dari fase AB-A (baseline-treatment-baseline) (Gravetter \& Forzano, 2012). Penelitian ini melibatkan seorang partisipan untuk melihat ada tidaknya hubungan sebab-akibat antara pemberian FCT terhadap target perilaku. Pengukuran target perilaku akan dilakukan pada sebelum, saat, dan sesudah intervensi. Penelitian ini telah dinyatakan memenuhi standar etis dan kode etik penelitian disiplin oleh Komite Etika Penelitian Fakultas Psikologi Universitas Indonesia.

Prosedur penelitian akan dibagi dalam tiga tahap, yaitu pra-intervensi, intervensi, dan pasca-intervensi. Sebelum penelitian dilaksanakan, peneliti memberikan informed 
consent terlebih dahulu kepada orang tua partisipan sambil menjelaskan prosedur tiap fase intervensi. Gambar 1 menunjukkan prosedur penelitian secara lebih jelas.

\section{Pra-intervensi}

Dalam tahap ini, terdapat tiga persiapan yang dilakukan sebelum masuk ke tahap intervensi. Hal pertama adalah melaksanakan Functional Behavior Assessment (FBA) untuk mengetahui fungsi perilaku bermasalah yang ditampilkan oleh $\mathrm{K}$ sebelumnya, yaitu perilaku meminta $\mathrm{K}$ dengan gestur. Proses FBA dilakukan dengan mengamati secara langsung perilaku meminta $\mathrm{K}$ di rumah selama 2 hari (90-120 menit). Pencatatan observasi menggunakan metode deskriptif dengan menulis deskripsi singkat mengenai anteseden, perilaku, dan konsekuensi setiap kali perilaku meminta dengan gesture K muncul.

Secara terperinci deskripsi FBA yang dimaksud adalah: (1) anteseden, yaitu situasi dimana K menginginkan suatu benda yang tidak bisa ia ambil sendiri, (2) perilaku, yaitu $\mathrm{K}$ menyampaikan keinginannya dengan menarik orang lain untuk mendekat kepada benda yang diinginkannya, dan (3) orang lain mengambilkan benda yang $\mathrm{K}$ inginkan.

Dari hasil FBA yang diterapkan, diperoleh bahwa fungsi dari perilaku meminta $\mathrm{K}$ dengan gesture adalah social positive reinforcement. Melalui positive reinforcement berupa benda yang diinginkan oleh $\mathrm{K}$, perilaku meminta dengan gesture terus bertahan. Oleh karena itu, target perilaku yang ingin dicapai untuk menggantikan perilaku bermasalah $\mathrm{K}$ yang sebelumnya adalah perilaku meminta dengan penukaran gambar. Target perilaku tersebut samasama berfungsi untuk mendapatkan benda yang diinginkan oleh K.

Hal kedua yang dilakukan dalam tahap persiapan adalah melakukan reinforcement assessment untuk menentukan benda yang paling menarik bagi $\mathrm{K}$ dan dapat menjadi reinforcement dalam intervensi. Reinforcement assessment dilakukan dengan mewawancarai ibu dan mengamati $\mathrm{K}$ pada saat yang sama dengan pelaksanaan FBA. Dari proses reinforcement assessment, terdapat 15 item yang terbagi dalam 3 kategori. Pada kategori benda, reinforcement yang disukai oleh $\mathrm{K}$ adalah televisi, HP, buku tulis, dan gymball. Pada ketegori makanan dan minuman, reinforcement yang disukai oleh $\mathrm{K}$ adalah roti, bolu, biskuit, susu, dan pisang. Pada kategori aktivitas, reinforcement yang disukai oleh $\mathrm{K}$ adalah mencuci pakaian, mencuci piring, menjemur, mengaduk adonan, dan menyetrika. Semua reinforcement tersebut akan dibuat dalam bentuk kartu bergambar yang akan ditukarkan selama intervensi.

Hal terakhir yang dilakukan pada tahap pra-intervensi ini adalah pengukuran baseline untuk mengidentifikasi sejauh mana kemampuan $\mathrm{K}$ dalam menukarkan gambar secara mandiri dan menghitung frekuensi perilaku meminta dengan penukaran gambar. Baseline dilaksanakan selama 3 hari berturut-turut dengan durasi sekitar 90120 menit. Dalam mengidentifikasi kemampuan K, PI akan mengukur seberapa jauh bantuan (prompt) yang dibutuhkan $\mathrm{K}$ untuk menampilkan perilaku menukarkan gambar. Sebagai contoh, ketika K tampak menginginkan sesuatu, PI akan memberikan verbal prompt (prompt dengan tingkat bantuan paling rendah) terlebih dahulu untuk mengetahui apakah K mampu menunjukkan perilaku penukaran gambar. Jika K belum mampu menunjukkan target perilaku dengan verbal prompt, PI akan lanjut mencoba dengan gestural, modeling, dan physical prompt (prompt dengan tingkat bantuan paling tinggi). PI memberikan prompt pada 5 kesempatan pertama dalam setiap periode observasi. Dalam menentukan frekuensi munculnya perilaku meminta dengan penukaran gambar, PI akan mengamati berapa kali $\mathrm{K}$ meminta suatu hal secara keseluruhan dan berapa kali $\mathrm{K}$ meminta dengan menukarkan gambar secara mandiri.

Hasil pengamatan dalam sesi baseline akan dicatat dalam lembar pencatatan perilaku yang berisi: jenis prompt yang dibutuhkan oleh $\mathrm{K}$ untuk dapat menampilkan target perilaku pada setiap kesempatan, jumlah $\mathrm{K}$ menampilkan perilaku meminta secara keseluruhan. Hasil baseline selama tiga hari dapat dilihat pada Tabel 1 .

Berdasarkan hasil baseline, tujuh kali K menolak prompt yang diberikan, enam kali $\mathrm{K}$ dapat menampilkan target perilaku dengan diberikan physical prompt, dan 2 kali dengan gestural prompt. Sementara itu, modeling prompt dinilai tidak efektif dalam membantu $\mathrm{K}$ memunculkan target perilaku. Dengan demikian, dalam program intervensi, $\mathrm{K}$ akan diajarkan membentuk perilaku penukaran kartu yang dimulai dari pemberian physical, gestural, dan kemudian verbal prompt, serta yang terakhir tanpa prompt. Selanjutnya, dari hasil baseline, $\mathrm{K}$ sama sekali tidak menampilkan perilaku meminta dengan penukaran gambar secara mandiri. $\mathrm{K}$ baru menampilkan target perilaku ketika diberikan prompt. Selain itu, dalam meminta sesuatu, K cenderung menggunakan bahasa tubuh, seperti menunjuk dan berteriak.

\section{Intervensi}

FCT diterapkan dengan menggunakan prosedur mostto-least prompting. Berdasarkan prosedur tersebut dan hasil baseline, intervensi terbagi menjadi empat fase, yaitu physicial prompt (Fase 1), gestural prompt (Fase 2), verbal prompt (Fase 3), dan tanpa prompt atau mandiri (Fase 4). Masing-masing fase terdiri dari dua sesi, tetapi dapat berubah sesuai dengan kemampuan partisipan dalam mencapai indikator keberhasilan pada masing-masing fase. Masing-masing sesi minimal terdiri dari 10 trial yang melibatkan PI sebagai pemberi prompt, partisipan, dan pasangan komunikasi. Dalam satu trial, partisipan akan dibuat tertarik dengan suatu benda, tetapi ia harus menampilkan perilaku penukaran gambar untuk memperoleh benda tersebut. Pada saat itu, PI memberikan prompt agar $\mathrm{K}$ menunju papan komunikasi, memilih, mengambil, dan memberikan gambar. Jika $\mathrm{K}$ berhasil menampilkan perilaku penukaran gambar dengan prompt, pasangan komunikasi akan memberikan benda yang 


\begin{tabular}{|c|c|c|}
\hline $\begin{array}{l}\text { Pra-intervensi } \\
\text { 1. Functional Behavioral } \\
\text { Assessment } \\
\text { 2. Reinforcement assessment } \\
\text { 3. Baseline dilaksanakan sehari } \\
\text { sebelum intervensi }\end{array}$ & $\begin{array}{c}\text { Intervensi } \\
\text { Empat fase yang mewakili tiap } \\
\text { jenis prompt (physical, gesture, } \\
\text { verbal dan tanpa prompt). } \\
\text { Tiap fase terdiri dari dua sesi } \\
\text { (total delapan sesi) }\end{array}$ & $\begin{array}{l}\text { Pasca-intervensi } \\
\text { 1. Pasca-tes dilaksanakan sehari } \\
\text { setelah intervensi } \\
\text { 2. Follow-up dilaksanakan } \\
\text { sebulan setelah intervensi } \\
\text { (masing-masing tiga hari) }\end{array}$ \\
\hline
\end{tabular}

Gambar 1. Prosedur penelitian.

Tabel 1. Hasil Baseline

\begin{tabular}{clc}
\hline Hari ke & Jenis prompt yang dibutuhkan per hari & Perilaku Meminta \\
\hline 1 & 4 kali K menolak prompt; 1 kali perilaku muncul dengan physical prompt. & $13 \mathrm{kali}$ \\
2 & $\begin{array}{l}1 \text { kali K menolak prompt; } 3 \text { kali perilaku muncul dengan physical prompt; } 1 \text { kali perilaku muncul } \\
\text { dengan gestural prompt. }\end{array}$ & 11 kali \\
3 & $\begin{array}{l}2 \text { kali K menolak prompt; } 2 \text { kali perilaku muncul dengan physical prompt; } 1 \text { kali perilaku muncul } \\
\text { dengan gestural prompt. }\end{array}$ & $10 \mathrm{kali}$ \\
\hline
\end{tabular}

Catatan: Perilaku penukaran gambar untuk ketiga jenis prompt tidak muncul $(0 \%)$

diinginkan oleh K. Pilihan gambar yang disediakan dalam satu papan komunikasi maksimal lima gambar. Selama intervensi, lima gambar tersebut tidak akan diberikan secara langsung dan bersamaan, tetapi secara bertahap jumlahnya akan meningkat dari sesi yang satu ke sesi berikutnya. Untuk lebih jelas, rancangan intervensi dapat dilihat pada Tabel 3 .

Dalam setiap sesi intervensi, terdapat lembar pencatatan perilaku yang berisi: fase dan prompt yang diberikan pada sesi tersebut, total trial yang diberikan, dan jenis prompt yang diberikan pada setiap trial. Kemudian, PI akan menghitung, dari total trial yang dilakukan, berapa trial ketika $\mathrm{K}$ berhasil menampilkan perilaku setelah diberikan prompt yang sesuai pada fase tersebut. Hasil perhitungannya akan dibuat dalam bentuk persentase. Jika pada sesi tersebut, hasil persentase telah mencapai indikator keberhasilan $(80 \%)$, maka $\mathrm{K}$ dapat melanjutkan ke fase yang berikutnya. Namun, jika pada sesi tersebut, hasil persentase belum mencapai indikator keberhasilan, maka sesi berikutnya masih berada di di fase yang sama sampai ia dapat mencapai indikator keberhasilan.

\section{Pasca-intervensi}

Pada tahap ini, PI akan melakukan pasca-tes dan followup. pasca-tes dilakukan untuk mengetahui ada tidaknya peningkatan frekuensi meminta dengan penukaran gambar antara sebelum dan sesudah intervensi. Pasca-tes dilaksanakan satu hari sesudah intervensi dilakukan. Selanjutnya, follow-up dilakukan untuk mengetahui apakah terdapat peningkatan frekuensi penukaran gambar setelah intervensi masih dapat bertahan. Follow-up dilakukan satu bulan setelah intervensi sudah tidak lagi diberikan. Baik pasca-tes maupun follow-up sama-sama dilakukan selama 3 hari berturut-turut dengan durasi sekitar 90-120 menit. Pasca-tes dan follow-up dilakukan dengan cara PI mengamati K secara langsung pada setting alami dan kemudian mencatat setiap kali partisipan menunjukkan perilaku meminta secara keseluruhan dan perilaku meminta dengan penukaran gambar dalam lembar pencatatan perilaku.

Hasil pengukuran yang dilakukan pada saat baseline, sesi intervensi, pasca-tes, dan follow-up akan disajikan secara visual menggunakan grafik. Intervensi FCT ini dianggap berhasil jika memenuhi dua indikator, yaitu (1) K mampu menguasai kemampuan perilaku meminta dengan penukaran gambar secara mandiri sebesar $80 \%$ dari trial yang diberikan dan (2) adannya peningkatan frekuensi perilaku meminta dengan penukaran gambar sebesar $80 \%$ pada saat pasca-tes. Artinya, $80 \%$ dari perilaku K meminta merupakan perilaku menukarkan gambar, bukan dengan cara lain seperti dengan gesture.

\section{Hasil}

Program intervensi dilaksanakan dalam 8 sesi dengan durasi sekitar 90 menit. Setting intervensi dilakukan di rumah partisipan antara lain paling banyak di area ruang keluarga, ruang makan, dan dapur. Seluruh intervensi dilaksanakan dengan ibu sebagai pasangan komunikasi. Terjadi beberapa perubahan dalam proses pemberian intervensi yang tidak sesuai dengan rancangan sebelumnya. Berdasarkan rancangan, setiap fase terdiri dari dua sesi untuk mencapai indikator keberhasilan. Namun, K hanya membutuhkan satu sesi untuk mencapai indikator keberhasilan pada Fase 1 (physical prompt). Di sisi lain, $\mathrm{K}$ membutuhkan tiga sesi untuk mencapai indikator keberhasilan Fase 4 (tanpa prompt) karena K cenderung menunggu PI memberikan prompt sementara seharusnya pada fase tersebut, tidak ada prompt yang diberikan. Pada saat $\mathrm{K}$ menunggu, $\mathrm{K}$ menjadi marah karena tidak segera mendapatkan objek yang ia inginkan tersebut sehingga ia menjadi lebih sulit diminta untuk menampilkan target perilaku secara mandiri. Selain itu, terdapat pelaksanaan sesi yang ditunda (sesi 6) pada keesokan harinya karena terdapat perubahan rutinitas $\mathrm{K}$ di 
Tabel 2. Rancangan intervensi FCT

\begin{tabular}{|c|c|c|c|}
\hline Fase & Jenis Prompt & Indikator Keberhasilan & Kegiatan \\
\hline 1 & Physical prompt & $\begin{array}{l}\text { Minimal } 80 \% \text { perilaku } \\
\text { penukaran gambar dibantu } \\
\text { dengan physical prompt }\end{array}$ & $\begin{array}{l}\text { Physical prompt diberikan dengan menarik tangan } \mathrm{K} \text { untuk } \\
\text { menuju ke papan komunikasi, mengarahkan tangannya untuk } \\
\text { mengambil gambar yang tepat, menyentuh tangan pasangan } \\
\text { komunikasi, dan meletakkan gambar di tangan pasangan } \\
\text { komunikasi. }\end{array}$ \\
\hline 2 & Gestural prompt & $\begin{array}{l}\text { Minimal } 80 \% \text { perilaku } \\
\text { penukaran gambar dibantu } \\
\text { dengan gestural prompt }\end{array}$ & $\begin{array}{l}\text { Gestural prompt diberikan dengan menunjuk ke arah papan } \\
\text { komunikasi, gambar yang harus } \mathrm{K} \text { ambil, dan ke arah ibu untuk } \\
\text { memberikan tanda bahwa } \mathrm{K} \text { harus memberikannya kepada ibu. }\end{array}$ \\
\hline 3 & Verbal prompt & $\begin{array}{l}\text { Minimal } 80 \% \text { perilaku } \\
\text { penukaran gambar dibantu } \\
\text { dengan verbal prompt }\end{array}$ & $\begin{array}{l}\text { Verbal prompt diberikan dengan mengatakan satu persatu "Pergi } \\
\text { ke (posisi papan komunikasi)", "Ambil gambar (benda yang } \\
\text { diinginkan)", dan setelah itu, "Berikan ke (pasangan komunikasi)". }\end{array}$ \\
\hline 4 & Tanpa prompt & $\begin{array}{l}\text { Minimal } 80 \% \text { perilaku } \\
\text { penukaran gambar tanpa } \\
\text { dibantu prompt }\end{array}$ & $\begin{array}{l}\text { PI hanya akan mengamati } \mathrm{K} \text { untuk menuju ke papan komunikasi, } \\
\text { memilih gambar, mengambil gambar, dan memberikannya kepada } \\
\text { pasangan komunikasi. }\end{array}$ \\
\hline
\end{tabular}

pagi hari yang membuat suasana hatinya menjadi buruk dan tidak dapat diarahkan untuk mengikuti sesi intervensi. Di luar situasi tersebut, secara umum $\mathrm{K}$ menunjukkan kondisi emosi yang cukup stabil, kooperatif, dan mampu menerima instruksi dengan baik.

Hasil penelitian akan dibagi menjadi 2, yaitu hasil tiap sesi intervensi yang menggambarkan kemampuan perilaku penukaran gambar yang ditampilkan $\mathrm{K}$ dan hasil perbandingan frekuensi perilaku meminta dengan penukaran gambar antara sebelum (baseline) dan setelah intervensi (pasca-tes dan follow-up).

\section{Hasil Tiap Sesi Intervensi}

Tujuan pertama dari penerapan FCT adalah meningkatkan penguasaan $\mathrm{K}$ untuk menampilkan perilaku meminta dengan menukarkan gambar secara mandiri atau tanpa bantuan. Indikator keberhasilan yang ingin dicapai adalah $\mathrm{K}$ mampu menguasai perilaku meminta dengan penukaran gambar secara mandiri sebanyak $80 \%$ dari trial yang diberikan. Secara terperinci pelaksanaan intervensi dapat dilihat pada Tabel 3 .

Berdasarkan hasil tabel di atas, $\mathrm{K}$ mampu mencapai indikator keberhasilan pada setiap fase. Pada sesi terakhir, $\mathrm{K}$ berhasil menampilkan perilaku meminta dengan penukaran gambar secara mandiri sebesar $84 \%$. Meskipun demikian, $\mathrm{K}$ membutuhkan waktu yang berbeda-beda dalam mencapai setiap fase tersebut. Pada Fase 1 dengan physical prompt, $\mathrm{K}$ hanya membutuhkan satu sesi saja untuk dapat mencapai indikator keberhasilan karena PI telah memberikan physical prompt untuk mengukur kemampuan $\mathrm{K}$ dalam menunjukkan perilaku meminta dengan penukaran gambar pada saat baseline. Pada Fase 2 dan Fase 3, K sama-sama membutuhkan dua sesi untuk dapat mencapai indikator keberhasilan. Hal tersebut menunjukkan bahwa ketika tingkat bantuan prompt yang diberikan menurun (Mis. dari physical menjadi gestural, gestural menjadi verbal prompt), K membutuhkan 1 sesi untuk melatih dirinya dalam menampilkan target perilaku.

Sementara itu, pada Fase 4, K membutuhkan waktu yang lebih lama (3 sesi) untuk dapat menampilkan target perilaku. Pada saat memasuki fase 4, ibu beberapa kali memberikan verbal prompt kepada K. Padahal, seharusnya, tidak ada prompt yang diberikan kepada $\mathrm{K}$ pada fase 4. Pemberian verbal prompt oleh ibu sudah dilakukan sejak sesi 5 sehingga terus berlanjut hingga sesi 6 yang seharusnya prompt jenis apapun tidak diberikan kembali.

Selain itu, pada sesi 6 , terdapat 3 trial di mana $\mathrm{K}$ menunjukkan emosi marah secara tiba-tiba sehingga ia membutuhkan physical dan gestural prompt untuk mengarahkan perilakunya dalam menukarkan gambar. Selanjutnya, pada sesi 7 , ibu sudah tidak terlalu banyak memberikan verbal prompt. K mulai mampu menunjukkan perilaku menukar gambar dengan mandiri. Namun, terdapat 3 trial ketika $\mathrm{K}$ membuat kesalahan dalam memilih gambar yang ia inginkan sehingga PI memberikan verbal prompt. Pada sesi $8, \mathrm{~K}$ dapat menunjukkan perilaku menukarkan gambar secara mandiri sebesar $84 \%$ dari trial. K membutuhkan sedikit verbal prompt untuk mengingatkan $\mathrm{K}$ dalam memperhatikan baik-baik pilihan gambar yang ada pada papan komunikasi.

Secara umum, K mampu memilih gambar dengan tepat di antara 5 gambar yang ada dalam 1 papan komunikasi. Saat penyusunan rancangan terdapat 15 gambar yang menjadi reinforcement bagi $\mathrm{K}$, yaitu televisi, pasir, buku dan pensil, gymball, puzzle, roti, bolu, biskuit, susu, pisang, mesin cuci (mencuci baju), jemuran (menjemur baju), spons (mencuci piring), adonan (mengocok adonan), dan setrika (menyetrika baju). Selain 15 gambar tersebut, terdapat penambahan 8 gambar lain yang kadang kala digunakan dalam intervensi, yaitu air putih, teh, jeruk, nasi, pensil warna, krayon, buku bacaan, dan boneka. Dengan demikian, total terdapat 23 gambar yang telah digunakan $\mathrm{K}$ selama intervensi ini.

\section{Hasil Perbandingan Baseline, Pasca-tes, dan Follow-Up}

Tujuan pertama dari penerapan FCT dalam penelitian ini adalah meningkatkan frekuensi $\mathrm{K}$ dalam menampilkan 
Tabel 3. Hasil pelaksanaan intervensi tiap sesi

\begin{tabular}{|c|c|c|c|c|c|c|}
\hline Fase & Indikator Keberhasilan & Sesi & $\begin{array}{l}\text { Total } \\
\text { Trial }\end{array}$ & $\begin{array}{l}\text { Target } \\
\text { Peri- } \\
\text { laku }\end{array}$ & $\begin{array}{l}\text { Keber- } \\
\text { hasilan } \\
(\%)^{*}\end{array}$ & Keterangan \\
\hline 1 & $\begin{array}{l}\text { Minimal } 80 \% \text { perilaku penukaran } \\
\text { gambar dibantu dengan physical } \\
\text { prompt }\end{array}$ & 1 & 14 & 12 & 86 & $\begin{array}{l}\text { Pada } 2 \text { trial yang lain, } \mathrm{K} \text { menolak } \\
\text { physical prompt. }\end{array}$ \\
\hline \multirow[t]{2}{*}{2} & $\begin{array}{l}\text { Minimal } 80 \% \text { perilaku penukaran } \\
\text { gambar dibantu dengan gestural } \\
\text { prompt }\end{array}$ & 2 & 16 & 5 & 31 & $\begin{array}{l}\text { Pada } 7 \text { trial yang lain, } \mathrm{K} \text { masih } \\
\text { membutuhkan physical prompt untuk } \\
\text { menampilkan target perilaku. Pada } \\
4 \text { trial yang lain, } \mathrm{K} \text { menolak physical } \\
\text { dan gestural prompt. }\end{array}$ \\
\hline & & 3 & 15 & 12 & 80 & $\begin{array}{l}\text { Pada } 3 \text { trial yang lain, } \mathrm{K} \text { masih } \\
\text { membutuhkan physical prompt untuk } \\
\text { menampilkan target perilaku. }\end{array}$ \\
\hline \multirow[t]{2}{*}{3} & $\begin{array}{l}\text { Minimal } 80 \% \text { perilaku penukaran } \\
\text { gambar dibantu dengan verbal } \\
\text { prompt }\end{array}$ & 4 & 10 & 5 & 50 & $\begin{array}{l}\text { Pada } 5 \text { trial yang lain, } \mathrm{K} \text { masih } \\
\text { membutuhkan physical dan gestural } \\
\text { prompt untuk menampilkan target } \\
\text { perilaku. }\end{array}$ \\
\hline & & 5 & 11 & 10 & 91 & $\begin{array}{l}\text { Pada } 1 \text { trial yang lain, } \mathrm{K} \text { masih } \\
\text { membutuhkan gestural prompt untuk } \\
\text { menampilkan target perilaku. }\end{array}$ \\
\hline \multirow[t]{3}{*}{4} & $\begin{array}{l}\text { Minimal } 80 \% \text { perilaku penukaran } \\
\text { gambar tanpa dibantu prompt }\end{array}$ & 6 & 12 & 4 & 33 & $\begin{array}{l}\text { Pada } 3 \text { trial yang lain, } \mathrm{K} \text { masih } \\
\text { membutuhkan gestural prompt } \\
\text { dan sedikit physical prompt untuk } \\
\text { menampilkan target perilaku. } \\
\text { Pada } 5 \text { trial yang lain, K masih } \\
\text { membutuhkan verbal prompt untuk } \\
\text { menampilkan target perilaku. }\end{array}$ \\
\hline & & 7 & 12 & 9 & 75 & $\begin{array}{l}\text { Pada } 3 \text { trial yang lain, } \mathrm{K} \text { masih } \\
\text { membutuhkan verbal prompt untuk } \\
\text { menampilkan target perilaku. }\end{array}$ \\
\hline & & 8 & 13 & 11 & 84 & $\begin{array}{l}\text { Pada } 2 \text { trial yang lain, } \mathrm{K} \text { masih } \\
\text { membutuhkan verbal prompt untuk } \\
\text { menampilkan target perilaku. }\end{array}$ \\
\hline
\end{tabular}

Catatan: * Persentase keberhasilan diperoleh dengan membagi target perilaku dengan total trial dan dikali $100 \%$

perilaku meminta dengan penukaran gambar. Indikator keberhasilan yang ingin dicapai adalah frekuensi perilaku meminta dengan penukaran gambar yang ditampilkan $\mathrm{K}$ sebanyak $80 \%$ dari total perilaku meminta $\mathrm{K}$ secara keseluruhan. PI telah mengukur frekuensi perilaku meminta dengan penukaran gambar antara sebelum (baseline) dan sesudah intervensi (pasca-tes) serta 1 bulan setelah intervensi tidak diberikan kembali (followup). Gambar 2 menunjukkan mengenai perbandingan persentasi frekuensi perilaku meminta dengan penukaran gambar yang ditunjukkan $\mathrm{K}$ antara baseline, pasca-tes, dan follow-up.

Berdasarkan hasil tabel dan grafik di atas, $\mathrm{K}$ menunjukkan adanya peningkatan frekuensi penukaran gambar yang cukup drastis antara sebelum dan sesudah intervensi. Sebelum intervensi, K sama sekali tidak mampu menukarkan gambar secara mandiri sehingga persentase frekuensi bernilai 0. Sesudah intervensi, K telah mampu menukarkan gambar secara mandiri sehingga terdapat peningkatan persentase frekuensi perilaku meminta dengan penukaran gambar sebanyak $89 \%$ dari keseluruhan jumlah perilaku meminta. Meskipun demikian, pencapaian hanya terjadi pada hari ke- 6 dan tidak konsisten terjadi pada harihari sebelumnya. Rata-rata persentase frekuensi perilaku penukaran gambar yang ditunjukkan $\mathrm{K}$ selama pasca-tes adalah $74 \%$ (diperoleh dengan menghitung rata-rata dari persentase penukaran gambar hari keempat [60\%], kelima [73\%], dan keenam [89\%]). Satu bulan setelah intervensi tidak diberikan kembali, $\mathrm{K}$ dapat mencapai indikator keberhasilan pada hari ke-7 dan ke-8. Rata-rata persentase frekuensi perilaku penukaran gambar selama followup lebih tinggi dibandingkan pada saat pasca-tes, yaitu $82 \%$ (diperoleh dengan menghitung rata-rata dari persentase penukaran gambar hari ketujuh [86\%], kedelapan [88\%], dan kesembilan [72\%]). Dengan demikian, setelah diberikan FCT, $\mathrm{K}$ menunjukkan adanya peningkatan frekuensi perilaku meminta dengan penukaran gambar bahkan 1 bulan setelah intervensi tidak diberikan kembali.

Peningkatan frekuensi perilaku meminta dengan penukaran gambar tidak muncul secara konsisten setiap hari. Pada hari-hari tertentu, seperti hari ke-4 dan ke-5, $\mathrm{K}$ masih menggunakan bahasa tubuh, berteriak, dan merengek ketika meminta sesuatu. Selain itu, pada hari ke-9, $\mathrm{K}$ cenderung menggunakan bahasa tubuh saat 


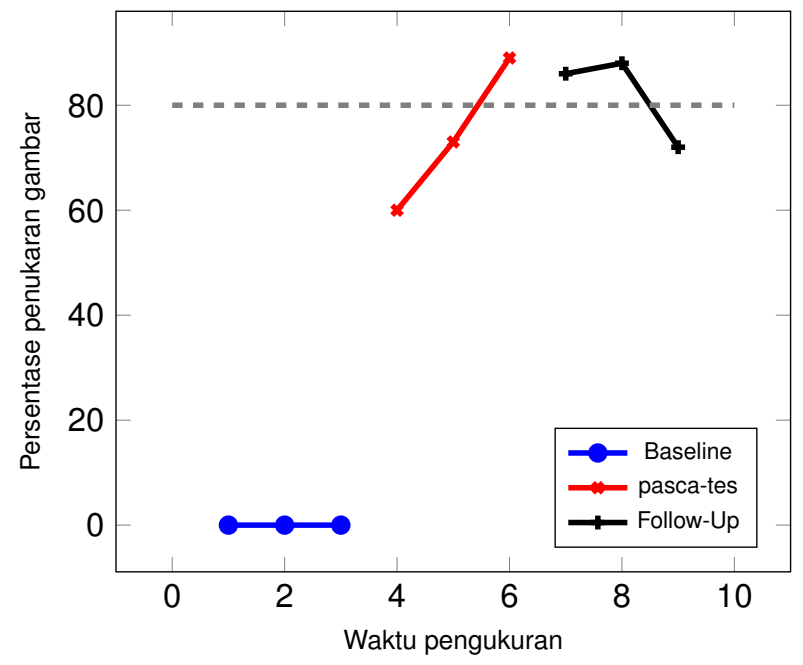

Gambar 2. Perbandingan target perilaku antara antara baseline, pasca-tes, dan follow-up. Target capaian 80

meminta kepada ayah atau kakak, seperti menarik tangan ayah untuk minta digendong atau menarik tangan kakak untuk mengajak bermain. Perilaku meminta dengan menggunakan gesture tersebut tidak muncul jika $\mathrm{K}$ meminta kepada ibu.

Secara umum, kemampuan $\mathrm{K}$ meminta dengan penukaran gambar telah memberikan beberapa dampak yang positif kepada keluarga. Berdasarkan hasil wawancara PI kepada ibu pada saat pasca-tes dan follow-up, ibu merasa lebih mudah untuk memahami keinginan $\mathrm{K}$ karena $\mathrm{K}$ sudah dapat memilih hal yang ia inginkan dan menyampaikannya dengan gambar kepada ibu. Sebelum intervensi, K cenderung akan tantrum ketika orang lain tidak dapat memahami yang ia inginkan. Setelah diajarkan perilaku menukarkan gambar, perilaku tantrum tersebut hampir tidak pernah $\mathrm{K}$ tampilkan karena saat $\mathrm{K}$ tampak mulai marah atau sedih, ibu dan ayah akan meminta K untuk memilih gambar yang ia inginkan. Selain itu, secara verbal, K mulai dapat menyebutkan suku kata terakhir dari benda yang ia inginkan. Sebelum intervensi, $\mathrm{K}$ cenderung mengimitasi bunyi suku kata terakhir dari suatu kata, sekarang $\mathrm{K}$ dapat menyebutkan suku kata terakhir dari suatu kata tanpa diberikan contoh oleh ibu. Misalnya, sebelum intervensi, ibu harus mengatakan, "Ro..ti.. Coba K ulangi, ro..." dan K baru akan menjawab "Ti". Saat ini, ibu hanya perlu berkata, "Ro..." dan K langsung dapat menjawab "Ti”.

\section{Diskusi}

Penelitian ini bertujuan untuk mengetahui efektivitas FCT pada anak dengan ASD yang diukur berdasarkan peningkatan penguasaan perilaku meminta dan frekuensi munculnya perilaku meminta tersebut antara sebelum dengan sesudah intervensi. Penerapan FCT yang diberikan kepada K secara efektif mampu meningkatkan kemampuan $\mathrm{K}$ dalam menampilkan perilaku meminta dengan penukaran gambar secara mandiri sebesar $84 \%$. Selain itu, frekuensi penukaran gambar juga meningkat menjadi $82 \%$ pada saat follow-up. Efektivitas FCT tersebut sejalan dengan penelitian sebelumnya yang dilakukan di negara lain (Anderson et al., 2016; Andzik et al., 2016; Durand \& Moskowitz, 2015; Lambert et al., 2012; Rispoli et al., 2014; Wacker et al., 2017). Sebagai salah satu penelitian di Indonesia yang menerapkan FCT pada anak dengan ASD, hasil penelitian ini menunjukkan bahwa, baik di Indonesia maupun di luar Indonesia, penerapan FCT dapat memberikan dampak positif terhadap kemampuan komunikasi anak, khususnya dalam perilaku meminta.

Selain peningkatan pada respon komunikatif, pemberian FCT dinilai mampu mengurangi perilaku tantrum partisipan. Hal tersebut sejalan dengan penelitian-penelitian sebelumnya yang menjelaskan bahwa, dengan FCT, peningkatan respon komunikatif terjadi dengan disertai penurunan perilaku bermasalah yang ditunjukkan partisipan, seperti tantrum dan agresi (Anderson et al., 2016; Andzik et al., 2016; Walker \& Snell, 2013). Hal tersebut dapat terjadi karena reinforcer diberikan ketika anak memunculkan respon komunikatif yang diinginkan yang dalam penelitian ini adalah perilaku meminta. Sementara itu, reinforcer tidak diberikan jika anak memunculkan perilaku tantrum atau agresi (Anderson et al., 2016; Dracobly \& Smith, 2012).

Sebelum memulai intervensi, penerapan FBA untuk mengetahui fungsi dari perilaku meminta dengan gesture yang ditampilkan oleh $\mathrm{K}$ dinilai menunjang keberhasilan FCT dalam penelitian ini. Beberapa penelitian sebelumnya menunjukkan bahwa intervensi yang melibatkan proses FBA memiliki efektivitas yang lebih kuat dibandingkan dengan intervensi yang tidak melibatkan proses FBA (Walker \& Snell, 2013). Mengetahui fungsi dari perilaku bermasalah penting untuk menentukan perilaku baru yang dibentuk serta prosedur dalam mengajarkan perilaku tersebut (Dracobly \& Smith, 2012). Perilaku baru yang ingin dibentuk harus memiliki fungsi yang sama (functional equivalence) dengan perilaku bermasalah sehingga pembentukan perilaku baru menjadi lebih mudah karena samasama menghasilkan reinforcer yang diinginkan (Durand \& Moskowitz, 2015). Dalam penelitian ini, perilaku bermasalah yang ditunjukkan $\mathrm{K}$ diubah menjadi perilaku meminta dengan penukaran gambar yang lebih mudah dipahami oleh orang lain. Perilaku meminta dengan penukaran gambar tersebut memiliki fungsi yang sama dengan perilaku meminta menggunakan gesture. Dengan demikian, benda-benda yang diinginkan oleh $\mathrm{K}$ diberikan hanya ketika $\mathrm{K}$ menunjukkan perilaku penukaran gambar sehingga perilaku meminta dengan gesture lama-kelamaan akan menghilang dan digantikan dengan perilaku baru berupa penukaran gambar tersebut.

Dalam penelitian ini, pemilihan respon komunikatif yang diajarkan memegang perang penting dalam keberhasilan FCT. Respon komunikatif yang dipilih untuk diintervensi pada kasus K adalah penukaran gambar. Selain memiliki fungsi yang sama dengan perilaku bermasalah, 
respon komunikatif yang diajarkan pada anak harus mudah untuk dipelajari, mudah dipahami oleh orang lain, dan dapat memperoleh imbalan yang diinginkan dengan cepat (Tiger et al., 2008). Kartu yang berisi gambar benda menjadi representasi visual terhadap apa yang diinginkan oleh anak sehingga anak memahami bahwa kartu gambar tersebut dapat menyampaikan keinginannya kepada orang lain mengenai benda yang sedang diinginkan (Williams \& Williams, 2011). Perilaku meminta dengan penukaran gambar terbukti cukup mudah dikuasai oleh $\mathrm{K}$ dibandingkan jika ia harus diajarkan secara verbal dalam meminta yang ia inginkan. Penggunaan gambar juga telah membantu orang tua untuk lebih mudah memahami apa yang sedang diinginkan oleh K. Selain itu, gambar yang digunakan telah tersedia di tempat-tempat yang mudah dijangkau oleh $\mathrm{K}$ sehingga cepat bagi $\mathrm{K}$ untuk dapat mengambil gambar dan memberikannya kepada orang lain.

Selain pelaksanaan FBA dan pemilihan respon komunikatif yang tepat, hal yang menunjang keberhasilan FCT dalam penelitian ini adalah pelaksanaan reinforcement assessment untuk menentukan secara spesifik benda yang benar-benar disukai oleh K. Sebagaimana dijelaskan oleh Skinner, perilaku verbal seseorang akan terbentuk jika perilaku verbal tersebut mendapatkan reinforcement dari pasangan komunikasi (Williams \& Williams, 2011). Artinya, reinforcement merupakan hal yang dapat menentukan apakah perilaku verbal akan tetap dilakukan secara berulang atau tidak. Hasil reinforcement assessment dalam penelitian ini membantu untuk memastikan bahwa bendabenda yang menjadi reinforcer benar-benar disukai oleh anak. Selain itu, adanya reinforcement assessment membantu orang tua dalam menyiapkan benda-benda yang diinginkan oleh partisipan sehingga pada saat intervensi, ketika $\mathrm{K}$ memberikan kartu berdasarkan benda yang ia inginkan, orang tua dapat langsung menukarkan kartu dengan benda yang diinginkan oleh partisipan tersebut. Dengan demikian, pada sesi intervensi selanjutnya, perilaku meminta dengan penukaran gambar dapat bertahan karena disertai dengan imbalan segera yang sesuai dengan keinginan anak.

Kemandirian $\mathrm{K}$ dalam menunjukkan perilaku meminta dengan penukaran gambar dibentuk melalui prosedur most-to-least prompting. Prosedur ini dinilai berhasil meningkatkan kemampuan $\mathrm{K}$ dalam menukarkan gambar secara mandiri. Dengan prosedur most-to-least prompting, perilaku dapat terbentuk ketika prompt yang diberikan secara bertahap dihilangkan atau dikurangi (Sarafino, 2012; Tiger et al., 2008). Ketika jenis prompt dengan tingkat bantuan yang lebih tinggi secara bertahap diturunkan menjadi jenis prompt dengan tingkat bantuan yang lebih rendah, hal tersebut membantu anak untuk mengurangi peluang munculnya kesalahan dalam menampilkan target perilaku. Minimnya peluang dalam membuat kesalahan membuat anak lebih mudah dalam membentuk target perilaku yang diinginkan secara bertahap (Franzone, 2009). Keberhasilan penerapan prosedur most-to-least prompting dalam penelitian ini sejalan dengan penelitian yang dilakukan oleh Rispoli et al. (2014) yang memaparkan bahwa penggunaan most-to-least prompting berhasil dalam mengajarkan perilaku penukaran gambar kepada anak prasekolah dengan gangguan perkembangan.

Dari hasil pengukuran, ditemukan bahwa terjadi peningkatan frekuensi penukaran gambar dari $74 \%$ saat beberapa hari setelah intervensi menjadi $82 \%$ saat satu bulan sesudah intervensi. Bertahannya perilaku meminta dengan penukaran gambar ini didukung oleh kelebihan pelaksanaan FCT yang melibatkan setting alami anak. (Durand \& Moskowitz, 2015) menjelaskan bahwa FCT merupakan salah satu intervensi yang cocok diberikan kepada anak usia dini karena melibatkan setting alami dalam keseharian anak. Artinya, respon komunikatif yang diajarkan di rumah atau sekolah dengan melibatkan orang terdekat, seperti orang tua dan guru, serta menggunakan reinforcer yang dibutuhkan anak sehari-hari membuat respon komunikatif lebih mudah terbentuk dan bertahan setelah intervensi tidak diberikan kembali.

Pada satu sisi, terjadi peningkatan frekuensi penukaran gambar sebulan setelah intervensi diberikan. Akan tetapi, peningkatan frekuensi tersebut tidak selalu konsisten di atas target pencapaian, yaitu $80 \%$. Salah satu keterbatasan penerapan FCT dalam penelitian ini adalah kurangnya proses generalisasi perilaku dalam setting dengan orang lain selain kepada ibu yang merupakan pasangan komunikasi dalam intervensi. Proses generalisasi merupakan tahap terakhir dalam prosedur penerapan FCT (Franzone, 2009; Tiger et al., 2008). Suatu intervensi modifikasi perilaku tidak hanya membentuk atau meningkatkan perilaku, tetapi juga mempertahankan perilaku tersebut di luar sesi intervensi (Franzone, 2009; Miltenberger, 2016). Hasil studi literatur yang dilakukan oleh (Falcomata \& Wacker, 2013) memaparkan bahwa efektivitas FCT dalam suatu setting tidak selalu diiringi dengan keberhasilan pada setting lain di luar intervensi. Oleh karena itu, penelitian yang menguji efektivitas FCT perlu untuk mengukur perilaku yang terjadi secara lebih lanjut pada berbagai setting di luar intervensi.

Generalisasi merupakan bagian dalam penerapan FCT untuk menciptakan suatu kesempatan di mana respon komunikatif dapat tergeneralisasi sehingga respon komunikatif tersebut dapat bertahan pada berbagai situasi dan kepada berbagai pasangan komunikasi (Franzone, 2009; Tiger et al., 2008). Falcomata \& Wacker (2013) menjelaskan bahwa perlu adanya strategi khusus yang dilakukan agar perilaku yang ingin dicapai dapat muncul pada setting yang lain. Salah satu strategi yang bisa dilakukan adalah dengan melakukan psikoedukasi atau pelatihan terhadap orang-orang terdekat anak yang berkaitan dengan munculnya perilaku bermasalah dan respon komunikatif (Durand \& Moskowitz, 2015). Hal ini bertujuan untuk memastikan bahwa konsekuensi yang diterima anak pada saat memunculkan perilaku bermasalah atau respon komunikatif di setting sehari-hari tetap sama dengan konsekuensi yang diberikan pada saat intervensi. Oleh karena itu, penelitian 
selanjutnya yang akan menerapkan prosedur generalisasi dapat melibatkan orang-orang terdekat anak untuk memahami bagaimana respon komunikatif yang diajarkan tetap bertahan selesai intervensi diberikan

Penelitian ini menunjukkan kurangnya reliabilitas dalam pengukuran hasil intervensi. Pengukuran terhadap penguasaan kemampuan dan frekuensi perilaku meminta dengan penukaran gambar dalam penelitian ini menggunakan pengamatan dari peneliti saja yang juga berperan sebagai PI. Pengukuran perilaku sebagai hasil dari suatu intervensi sebaiknya dilakukan lebih dari satu orang (interobserver) untuk dapat menghindari adanya bias dan memperoleh hasil pengukuran yang konsisten dan dapat dipercaya Martin \& Pear (2015); Miltenberger (2016). Oleh karena itu, penelitian berikutnya dapat melibatkan seorang observer untuk dapat membandingkan pengukuran perilaku sehingga hasil penelitian menjadi lebih dapat dipercaya.

Kelemahan lain dalam penelitian ini adalah tidak adanya pencatatan secara spesifik mengenai jumlah gambar yang dapat ditukarkan oleh $\mathrm{K}$ untuk memperoleh benda yang diinginkan setelah intervensi selesai diberikan. Penukaran gambar dalam berkomunikasi merupakan salah satu bentuk dari augmentative and alternative communication system (AAC) yang dapat digunakan sebagai pengganti dari komunikasi secara lisan Walker \& Snell (2013). Sebagai bagian dari perkembangan kemampuan komunikasi anak, penelitian menunjukkan bahwa peningkatan frekuensi perilaku penukaran gambar biasanya disertai dengan peningkatan keluasan kosa kata gambar yang dimiliki anak sehingga jumlah kartu bergambar yang digunakan akan semakin banyak Heryati \& Ratnengsih (2017). Sayangnya, dalam penelitian ini, pencatatan mengenai jumlah gambar yang dibutuhkan hanya dilakukan pada saat sesi intervensi. Pada saat pasca-tes dan follow-up, tidak ada pencatatan mengenai gambar apa saja yang ditukarkan oleh K. Penelitian selanjutnya yang akan menggunakan FCT dengan respon komunikatif yang diajarkan berupa perilaku penukaran gambar perlu untuk mencatat secara rinci bagaimana perkembangan jumlah kosakata gambar anak sesudah intervensi diberikan.

\section{Kesimpulan}

Berdasarkan hasil penelitian, dapat disimpulkan bahwa penerapan FCT secara efektif dapat meningkatkan kemampuan anak dengan ASD dalam meminta dengan menukarkan gambar. Peningkatan kemampuan pada partisipan mencapai indikator keberhasilan intervensi dengan persentase kemampuan penukaran gambar sebanyak $84 \%$ dari trial yang diberikan. Selanjutnya, FCT juga terbukti berhasil meningkatkan frekuensi perilaku meminta dengan penukaran gambar antara baseline, pasca-tes, dan followup. Pada saat pasca-tes, rata-rata $\mathrm{K}$ menukarkan gambar saat meminta sebesar $74 \%$, sementara pada saat followup, frekuensi rata-rata $\mathrm{K}$ meminta dengan penukaran gambar naik menjadi $82 \%$. Meskipun demikian, peningkatan perilaku meminta dengan penukaran gambar tidak muncul secara konsisten setiap harinya.

Hasil penelitian ini memberikan implikasi terhadap pentingnya mengetahui fungsi dari perilaku bermasalah sebelum intervensi dilaksanakan. Pemilihan respon komunikatif yang akan diajarkan dalam intervensi sebaiknya memiliki fungsi yang sama dengan fungsi dari perilaku bermasalah. Oleh karena itu, setiap pakar klinis ataupun terapis yang ada di Indonesia perlu untuk melakukan FBA terlebih dahulu untuk memastikan jenis respon komunikatif apa yang tepat untuk diajarkan kepada anak dengan ASD. Selain itu, penelitian terkait efektivitas FCT di Indonesia masih membutuhkan penelitian lanjutan dengan jumlah partisipan yang lebih banyak dan karakteristik atau gangguan yang lain selain ASD. Penelitian berikutnya juga perlu melibatkan prosedur generalisasi dan mengukur efektivitas prosedur tersebut terhadap konsistensi dari respon komunikatif di luar setting intervensi. Selain itu, pengukuran yang reliabel juga dibutuhkan untuk memastikan bahwa hasil dari intervensi FCT dapat dipercaya.

\section{Referensi}

American Psychiatric Association. (2013). Diagnostic and Statistical Manual of Mental Disorders: DSM-5 (5th ed.). Author.

Anderson, E., Barretto, A., McLaughlin, T. F., \& McQuaid, T. (2016). Effects of functional communication training with and without delays to decrease aberrant behaviour in a child with autism spectrum disorder. Journal on Developmental Disabilities, 22(1), 101-110.

Andzik, N. R., Cannella-Malone, H. I., \& Sigafoos, J. (2016). Practitioner-implemented functional communication training: A review of the literature. Research and Practice for Persons with Severe Disabilities, 41(2), 79-89. https: //doi.org/10.1177/1540796916633874

Ardiwijaya, R. P., \& Kuntoro, I. A. (2019). Penerapan differential reinforcement of alternative behavior untuk menurunkan screen-time pada anak dengan language disorder. Journal of Psychological Science and Profession, 3(1), 57. https: //doi.org/10.24198/jpsp.v3i1.21507

Carr, E. G., \& Durand, V. M. (1985). Reducing behavior problems through Functional Communication Training. Journal of Applied Behavior Analysis, 18(2), 111-126. https://doi.org/ 10.1901/jaba.1985.18-111

Dracobly, J. D., \& Smith, R. G. (2012). Progressing from identification and functional analysis of precursor behavior to treatment of self-injurious behavior. Journal of Applied Behavior Analysis, 45(2), 361-374. https://doi.org/10.1901/ jaba.2012.45-361

Durand, V. M., \& Moskowitz, L. (2015). Functional communication training: Thirty years of treating challenging behavior. Topics in Early Childhood Special Education, 35(2), 116-126. https://doi.org/10.1177/0271121415569509

Falcomata, T. S., \& Wacker, D. P. (2013). On the use of strategies for programming generalization during functional 
communication training: A review of the literature. Journal of Developmental and Physical Disabilities, 25(1), 5-15. https://doi.org/10.1007/s10882-012-9311-3

Franzone, E. (2009). Steps for implementation: Functional communication training. The National Professional Development Center on Autism Spectrum Disorders. Waisman Center, University of Wisconsin. http://autismpdc.fpg.unc.edu

Gravetter, F. J., \& Forzano, L. B. (2012). Research methods for the behavioral sciences (4th ed.). Wadsworth.

Heryati, E., \& Ratnengsih, E. (2017). Penggunaan metode PECS (picture exchange communication system) untuk meningkatkan kemampuan komunikasi anak autis. Pedagogia, 15(1), 31-38. https://doi.org/10.17509/pedagogia. v15i1.6558

Jusoh, W., \& Majid, R. A. (2017). Using picture exchange communication system to improve speech utterance among children with autism. Journal of ICSAR, 1(1), 46-49. https: //doi.org/10.17977/um005v1i12017p046

Kim, S. H., Paul, R., Tager-Flusberg, H., \& Lord, C. (2014). Language and communication in autism. In F. R. Volkmar, S. J. Rogers, R. Paul, \& K. A. Pelphrey (Eds.), Handbook of autism and pervasive developmental disorder: Diagnosis, development, and brain mechanism (4th ed., pp. 230-262).

Konst, M. J., Matson, J. L., \& Turygin, N. (2013). Exploration of the correlation between autism spectrum disorder symptomology and tantrum behaviors. Research in Autism Spectrum Disorders. https://doi.org/10.1016/j.rasd.2013.05. 006

Lambert, J. M., Bloom, S. E., \& Irvin, J. (2012). Trial-based functional analysis and functional communication training in an early childhood setting. Journal of Applied Behavior Analysis, 45(3), 579-584. https://doi.org/10.1901/jaba.2012. 45-579

Martin, G., \& Pear, J. (2015). Behavior modification: What it is and how to do it (10th ed.). Pearson Education.

Mash, E. J., \& Wolfe, D. A. (2016). Abnormal child psychology (6th ed.). Cengage Learning.

Miltenberger, R. G. (2016). Behavior modification: Principles and procedures (6th ed.). Cengage Learning.

Mody, M., \& Belliveau, J. W. (2012). Speech and language impairments in autism: Insights from behavior and neuroimaging. American Chinese Journal of Medicine and Science, 5(3), 157. https://doi.org/10.7156/v5i3p157

Murwati, A. (2013). Meningkatkan kemampuan komunikasi meminta pada anak autis melalui PECS. Universitas Muhammadiyah Surakarta.
Putri, C. R. R., Hastuti, W. D., \& Adi, E. P. (2018). The influence the Picture Exchange Communication System method toward the communication ability of autistic child. Journal of ICSAR, 2(2), 180-185. https://doi.org/10.17977/ um005v2i22018p180

Rispoli, M., Camargo, S., Machalicek, W., Lang, R., \& Sigafoos, J. (2014). Functional communication training in the treatment of problem behavior maintained by access to rituals. Journal of Applied Behavior Analysis, 47(3), 580-593. https://doi.org/10.1002/jaba.130

Rodriguez, G., Hartley, S. L., \& Bolt, D. (2019). Transactional relations between parenting stress and child autism symptoms and behavior problems. Journal of Autism and Developmental Disorders, 49(5), 1887-1898. https://doi.org/ 10.1007/s10803-018-3845-x

Santrock, J. (2014). Child Development (14th ed.). McGraw Hill.

Sarafino, E. P. (2012). Applied behavior analysis: Principles and procedures in behavior modification. John Wiley \& Sons, Inc.

Stephanie, G., \& Djuwita, E. (2019). Efektivitas teknik antescedent control dan differential reinforcement of alternative behavior untuk menurunkan frekuensi pica. Seurune Jurnal Psikologi Unsyiah, 2(2), 44-67. https://doi. org/10.24815/s-jpu.v2i2.14207

Tiger, J. H., Hanley, G. P., \& Bruzek, J. (2008). Functional communication training: A review and practical guide. Behavior Analysis in Practice, 1(1), 16-23. https://doi.org/ $10.1007 / \mathrm{bf03391716}$

Vistasari, R., \& Patria, B. (2019). Program PECS (picture exchange communication system) untuk meningkatkan kemampuan berbicara terstruktur pada anak autis. Gadjah Mada Journal of Professional Psychology (GamaJPP), 5(1), 94-107. https://doi.org/10.22146/gamajpp.48590

Wacker, D. P., Schieltz, K. M., Berg, W. K., Harding, J. W., Padilla Dalmau, Y. C., \& Lee, J. F. (2017). The long-term effects of functional communication training conducted in young children's home settings. Education and Treatment of Children, 40(1), 43-56. https://doi.org/10.1353/etc.2017. 0003

Walker, V. L., \& Snell, M. E. (2013). Effects of augmentative and alternative communication on challenging behavior: A meta-analysis. AAC: Augmentative and Alternative Communication, 29(2), 117-131. https://doi.org/10.3109/ 07434618.2013.785020

Williams, B. F., \& Williams, R. L. (2011). Effective programs for treating autism spectrum disorder: Applied behavior analysis models. Routledge. 